\title{
TEM OBSERVATION OF THE Ti INTERLAYER BETWEEN SiC SUBSTRATES DURING
} DIFFUSION BONDING

\author{
H. Tsuda ${ }^{1}$, S. Mori ${ }^{1}$, M. C. Halbig ${ }^{2}$ and M. Singh ${ }^{3}$ \\ ${ }^{1}$ Graduate School of Engineering, Osaka Prefecture University, Osaka, Japan \\ ${ }^{2}$ NASA Glenn Research Center, Cleveland, Ohio, USA \\ ${ }^{3}$ Ohio Aerospace Institute, NASA Glenn Research Center, Cleveland, Ohio, USA
}

\section{ABSTRACT}

Diffusion bonding was carried out to join $\mathrm{SiC}$ to $\mathrm{SiC}$ substrates using titanium interlayers. In this study, $10 \mu \mathrm{m}$ and $20 \mu \mathrm{m}$ thick physical vapor deposited (PVD) Ti surface coatings, and 10 and $20 \mu \mathrm{m}$ thick Ti foils were used. Diffusion bonding was performed at $1250^{\circ} \mathrm{C}$ for PVD Ti coatings and $1200^{\circ} \mathrm{C}$ for $\mathrm{Ti}$ foil. This study investigates the microstructures of the phases formed during diffusion bonding through TEM and selected-area diffraction analysis of a sample prepared with an FIB, which allows samples to be taken from the reacted area. In all samples, $\mathrm{Ti}_{3} \mathrm{SiC}_{2}, \mathrm{Ti}_{5} \mathrm{Si}_{3} \mathrm{C}_{\mathrm{x}}$ and $\mathrm{TiSi}_{2}$ phases were identified. In addition, $\mathrm{TiC}$ and unknown phases also appeared in the samples in which Ti foils were used as interlayers. Furthermore, $\mathrm{Ti}_{3} \mathrm{SiC}_{2}$ phases show high concentration and $\mathrm{Ti}_{5} \mathrm{Si}_{3} \mathrm{C}_{\mathrm{x}}$ formed less when samples were processed at a higher temperature and thinner interlayer samples were used. It appears that the formation of microcracks is caused by the presence of intermediate phase $\operatorname{Ti}_{5} \mathrm{Si}_{3} \mathrm{C}_{\mathrm{x}}$, which has anisotropic thermal expansion, and by the presence of an unidentified Ti-Si-C ternary phase with relatively low $\mathrm{Si}$ content.

\section{INTRODUCTON}

Silicon carbide $(\mathrm{SiC})$ is a very promising material for high-temperature structural and extreme environment applications due to its excellent high temperature mechanical properties, oxidation resistance and thermal stability. Therefore, $\mathrm{SiC}$ has been used in a wide range of practical applications, not only as a monolithic material, but also as matrix and fiber reinforcement materials in composites ${ }^{1}$. However, further practical applications of complex shaped $\mathrm{SiC}$ components are hindered by geometrical limitations of current fabrication methods (i.e. hot pressing and chemical vapor deposition). To overcome this problem, joining approaches are being developed as a solution to fabricating large, three dimensional components from simpler-shaped ceramics. Various joining methods are being developed using reaction bonding ${ }^{2-4}$ and brazing ${ }^{5-6}$.

In previous studies, Gottselig et $\mathrm{al}^{7}$ and Naka et $\mathrm{al}^{8}$ have reported the bonding of silicon carbide with titanium and phase reaction and diffusion path in the ternary system. However, processing conditions were different and the microstructural analysis was not presented in detail. In previous studies, we have reported the details of various phases that form in the bonded area during diffusion bonding of $\mathrm{SiC}$ to $\mathrm{SiC}$ using scanning electron microscopy (SEM), X-ray diffraction (XRD) analysis, and energy dispersive spectroscopy (EDS) as well as electron microprobe analysis (EMPA) ${ }^{9-11}$.

In this study, diffusion bonding was utilized to join $\mathrm{SiC}$ to $\mathrm{SiC}$ using two types of Ti interlayers. The first was a PVD Ti coating on the surface of $\mathrm{SiC}$ substrates, and the other was thin metallic Ti foil. After diffusion bonding, the effects of interlayer type, thickness, and processing temperature were studied in detail by analyzing the microstructure and phase formation. This paper contains detailed microstructural analysis of the phases formed during diffusion bonding through TEM and selected-area diffraction (SAD) analysis of samples prepared with an FIB (focused ion beam), which allows samples to be taken from the reacted area.

\section{EXPERIMENTAL}

CVD $\beta$-SiC substrates were obtained from Rohm \& Hass (Woburn, MA). One interlayer type used for joining was titanium metallic foil from Goodfellow Corporation (Glen Burnie, MD) with 
thicknesses of 10 and $20 \mu \mathrm{m}$. A second interlayer type consisted of titanium coatings with a thickness of $10 \mu \mathrm{m}$ which were applied in-house employing physical vapor deposition (PVD). To obtain a $10 \mu \mathrm{m}$ PVD Ti interlayer, one coated and one uncoated SiC substrate were matched. To obtain a $20 \mu \mathrm{m}$ PVD Ti interlayer, two surface $\mathrm{Ti}$ coated $\mathrm{SiC}$ substrates were matched. Before joining, all materials were ultrasonically cleaned in acetone for 10 minutes. Joints formed using PVD Ti coated SiC were diffusion bonded at $1250^{\circ} \mathrm{C}$ with a clamping pressure of $24 \mathrm{MPa}$. Joints formed using 10 and $20 \mu \mathrm{m} \mathrm{Ti}$ foil as the interlayer were diffusion bonded at $1200^{\circ} \mathrm{C}$ with a clamping pressure of $30 \mathrm{MPa}$. All joint processing was conducted in a vacuum environment with a $2 \mathrm{hr}$ hold at the peak temperature under load followed by a slow cool down at a cooling rate of $5^{\circ} \mathrm{C}$ per minute.

Elemental analysis and phase identification was conducted on carbon coated samples using EMPA (JEOL 8200 Super Probe) for the bonds formed with PVD Ti and using SEM (JEOL, JXA-8900) for bonds formed with the Ti foil. Both were coupled with EDS. All samples for TEM were prepared by FIB (FEI, Quant 3D). The preparation process is described in detail in the literature ${ }^{12}$. By preparing the TEM specimen using the FIB, a clean, less-damaged, and precisely selected thin specimen was obtained, in contrast to specimens obtained using other methods, such as ion milling. Thus, the FIB allows the preparation of a TEM sample from the diffusion bonded area. Transmission electron microscopy (TEM) was conducted at 200kV (JEOL, JEM-2000FX).

\section{RESULTS AND DISCUSSION}

SEM Microstructure of Diffusion Bonded Samples

In Figures 1 (a) and (b), EMPA back-scattered electron images of the diffusion bonds are shown for when $10 \mu \mathrm{m}$ (sample 1) and $20 \mu \mathrm{m}$ (sample 2) thick PVD Ti coatings were used as the interlayers, respectively. In Table 1, the compositions as determined by EDS are listed for all phases identified in the diffusion bonds of sample 1 and sample 2. Microcracks can be seen and there exist three phases in the bond for the thicker $20 \mu \mathrm{m}$ layer (Fig. 1(b)). The phases labeled A2, B2, and C2 were identified as $\mathrm{Ti}_{3} \mathrm{SiC}_{2}, \mathrm{TiSi}_{2}$, and $\mathrm{Ti}_{5} \mathrm{Si}_{3} \mathrm{C}_{\mathrm{x}}$, respectively. On the other hand, the bond formed with the thinner $10 \mu \mathrm{m}$ layer, as seen in Fig. 1(a), did not have microcracking. The two phases of $\mathrm{Ti}_{3} \mathrm{SiC}_{2}$ (phase A1) and $\mathrm{TiSi}_{2}$ (phase B1) were again identified. The phases identified are consistent with the results of Gottselig et $\mathrm{al}^{7}$. The $\mathrm{Ti}_{5} \mathrm{Si}_{3} \mathrm{C}_{\mathrm{x}}$ phase was not observed in the thinner bond. Naka et al ${ }^{8}$ suggested that $\mathrm{Ti}_{5} \mathrm{Si}_{3} \mathrm{C}_{\mathrm{x}}$ is an intermediate phase that is not present when phase reactions have gone to completion.

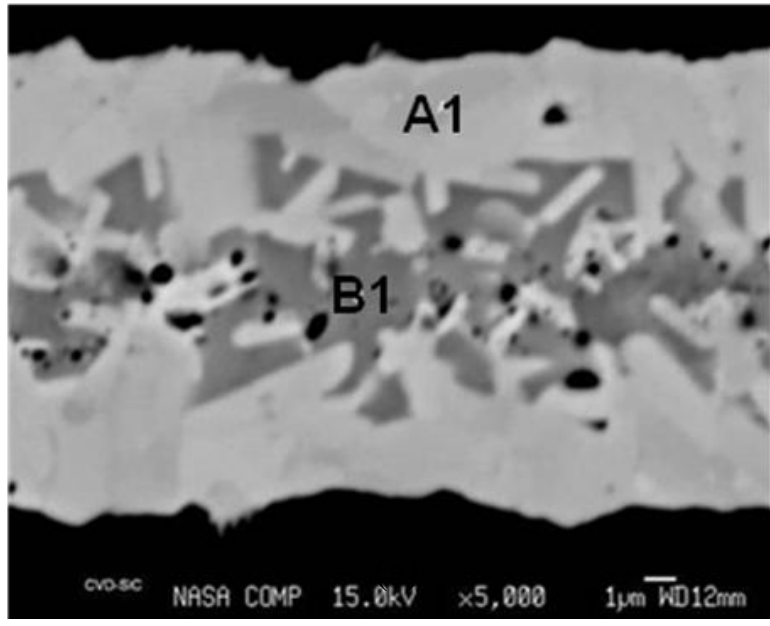

(a)

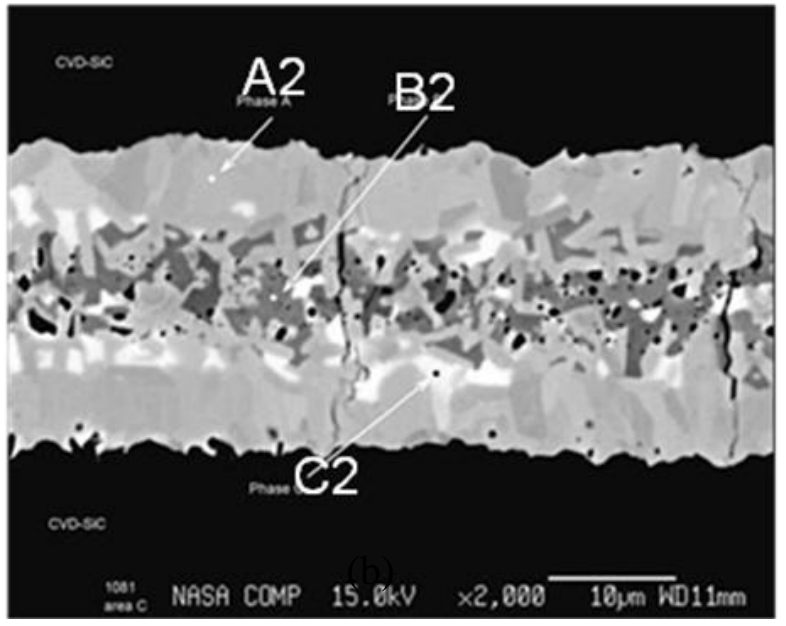

(b)

Figure 1. EMPA back-scattered electron images of diffusion bond of sample 1 (a) and 2 (b). 
Table 1. Compositions of phases determined by EDS.

\begin{tabular}{|c|c|c|c|c|c|}
\hline \multirow{2}{*}{ Sample } & \multirow{2}{*}{$\begin{array}{c}\text { Phase } \\
\text { Label }\end{array}$} & \multicolumn{3}{|c|}{$\begin{array}{c}\text { Composition in } \\
\text { Atomic } \%\end{array}$} & $\begin{array}{c}\text { Probable } \\
\text { phase }\end{array}$ \\
\cline { 3 - 6 } & & $\mathrm{C}$ & $\mathrm{Si}$ & $\mathrm{Ti}$ & \\
\hline \multirow{2}{*}{$\begin{array}{c}\text { Sample } \\
1\end{array}$} & $\mathrm{~A} 1$ & 25 & 19 & 56 & $\mathrm{Ti}_{3} \mathrm{SiC}_{2}$ \\
\hline \multirow{2}{*}{$\begin{array}{c}\text { Sample } \\
2\end{array}$} & $\mathrm{~A} 2$ & 26 & 61 & 36 & $\mathrm{TiSi}_{2}$ \\
\cline { 2 - 6 } & $\mathrm{B} 2$ & 2 & 62 & 36 & $\mathrm{TiSi}_{2}$ \\
\cline { 2 - 6 } & $\mathrm{C} 2$ & 7 & 34 & 59 & $\mathrm{Ti}_{5} \mathrm{Si}_{3} \mathrm{C}_{\mathrm{x}}$ \\
\hline
\end{tabular}

Figures 2(a) and (b) show the diffusion bonds formed with $10 \mu \mathrm{m}$ (sample 3) and $20 \mu \mathrm{m}$ (sample 4) thick Ti foils and Table 2 gives the compositions of the phases identified in each joint. The two joints shared two phases, labeled $\mathrm{A}$ and $\mathrm{B}$ in Table 2 and in the corresponding micrographs. The composition for phase $\mathrm{A}$ was in the range of 51-55C/13-14Si/32-35Ti (referred to as common phase A) and that for phase B was 38-47C/22-27Si/31-35Ti (referred to as common phase B). In sample 3, microcracks were scarcely observed or only very minimal microcracks were observed. However, in sample 4, significant microcracking was observed and an example of a typical microcrack is shown in Figure 2 (b). The microcracking seemed to be caused by the presence of labeled $\mathrm{C}$ phase. This will be discussed later.

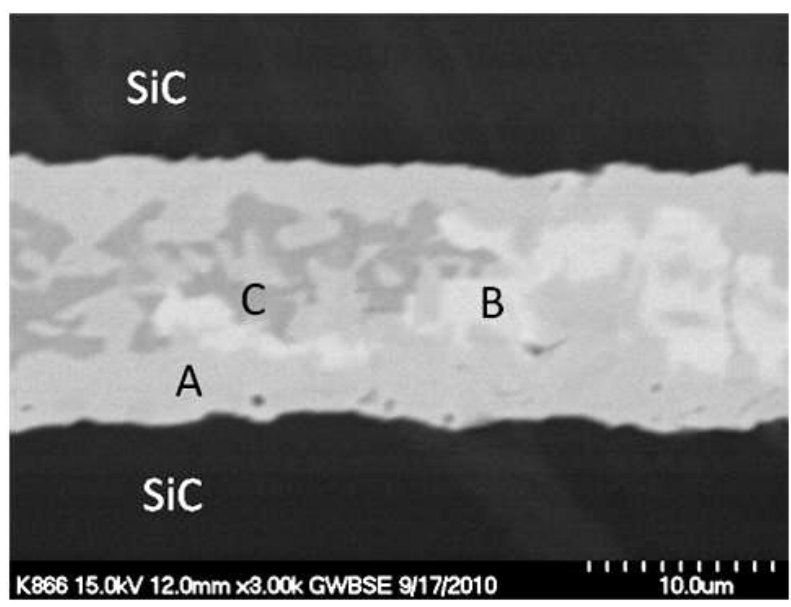

(a)

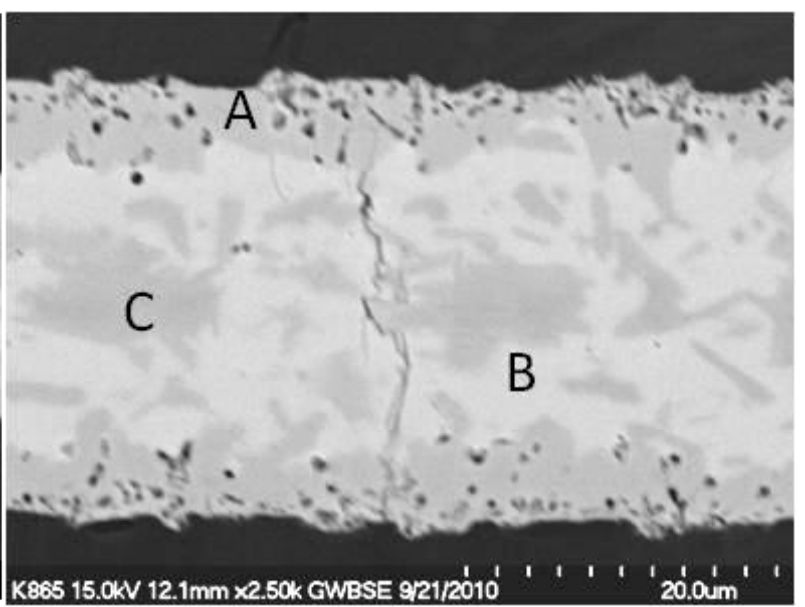

(b)

Figure 2. SEM micrographs of diffusion bond of sample 3 (a) and 4 (b).

Table 2. Compositions of phases determined by EDS.

\begin{tabular}{|c|c|c|c|c|c|}
\hline \multirow{2}{*}{ Sample } & \multirow{2}{*}{$\begin{array}{l}\text { Phase } \\
\text { Label }\end{array}$} & \multicolumn{3}{|c|}{$\begin{array}{l}\text { Composition in } \\
\text { Atomic \% }\end{array}$} & \multirow{2}{*}{$\begin{array}{l}\text { Common and } \\
\text { Unique Phases }\end{array}$} \\
\hline & & $\mathrm{C}$ & $\mathrm{Si}$ & $\mathrm{Ti}$ & \\
\hline \multirow{3}{*}{$\begin{array}{c}\text { Sample } \\
3\end{array}$} & A & 51 & 14 & 35 & common phase $\mathrm{A}$ \\
\hline & B & 38 & 27 & 35 & common phase B \\
\hline & $\mathrm{C}$ & 37 & 43 & 20 & $\begin{array}{l}\text { phase unique to this } \\
\text { condition }\end{array}$ \\
\hline \multirow{3}{*}{$\begin{array}{c}\text { Sample } \\
4\end{array}$} & A & 55 & 13 & 32 & common phase A \\
\hline & B & 47 & 22 & 31 & common phase $\mathrm{B}$ \\
\hline & $\mathrm{C}$ & 58 & 7 & 35 & $\begin{array}{c}\text { common phase A } \\
\text { with lower } \mathrm{Si} \\
\text { content }\end{array}$ \\
\hline
\end{tabular}


TEM of Diffusion Bonded Samples

TEM observations were conducted to examine in detail the microstructures of formed phases in the four diffusion bonded samples. Figure 3 shows the TEM micrograph of the sample in which $10 \mu \mathrm{m}$ thick PVD Ti was used as the interlayer. It is clearly shown that the diffusion bond consists of many small reaction formed grains with length of $2 \sim 4 \mu \mathrm{m}$, and width of $1 \sim 2 \mu \mathrm{m}$. SAD patterns have been taken at locations which are shown in numerical order in the figure and the probable phases are summarized in Table 3. This type of detailed phase identification was conducted for all four samples with phases of about 30 grains in each sample determined from SAD pattern analysis (individual phases are distinguished by the differently shaped marks in the micrographs and are listed in corresponding tables). In addition, Table 4 gives the calculated percentage content of each phase. Fig. 4 shows SAD patterns of individual phases of sample 1. The TEM analysis indicates that sample 1 consists of three phases, namely $\mathrm{Ti}_{3} \mathrm{SiC}_{2}, \mathrm{Ti}_{5} \mathrm{Si}_{3} \mathrm{C}_{\mathrm{x}}$, and $\mathrm{TiSi}_{2}$. Calculated fractions of phases formed during diffusion bonding are $91.4 \% \mathrm{Ti}_{3} \mathrm{SiC}_{2}, 2.9 \% \mathrm{Ti}_{5} \mathrm{Si}_{3} \mathrm{C}_{\mathrm{x}}$, and $5.7 \% \mathrm{TiSi}_{2}$. Naka et al. ${ }^{8}$ confirmed the presence of $\mathrm{Ti}_{3} \mathrm{SiC}_{2}$ and $\mathrm{TiSi}_{2}$ in the final stage of processing by XRD when $\mathrm{Ti}$ was used to join $\mathrm{SiC}$ to $\mathrm{SiC}$. As mentioned above, $\mathrm{Ti}_{3} \mathrm{SiC}_{2}$ is the primary phase and the fractions of other phases are extremely small. This suggests that the reaction between the SiC substrate and the $10 \mu \mathrm{m}$ PVD Ti coating interlayer may have been complete in sample 1 .

Table 3. Summary of probable phases determined from SAD patterns.

\begin{tabular}{|c|c|c|c|c|c|c|c|c|c|}
\hline No & Sample 1 & Sample2 & Sample3 & Sample4 & No & Sample 1 & Sample2 & Sample3 & Sample4 \\
\hline 1 & $\mathrm{Ti}_{5} \mathrm{Si}_{3} \mathrm{Cx}$ & $\mathrm{Ti}_{3} \mathrm{SiC}_{2}$ & $\mathrm{Ti}_{3} \mathrm{SiC}_{2}$ & $\mathrm{Ti}_{3} \mathrm{SiC}_{2}$ & 19 & $\mathrm{Ti}_{3} \mathrm{SiC}_{2}$ & $\mathrm{Ti}_{3} \mathrm{SiC}_{2}$ & $\mathrm{Ti}_{3} \mathrm{SiC}_{2}$ & $\mathrm{TiC}$ \\
\hline 2 & $\mathrm{Ti}_{3} \mathrm{SiC}_{2}$ & $\mathrm{Ti}_{3} \mathrm{SiC}_{2}$ & $\mathrm{Ti}_{3} \mathrm{SiC}_{2}$ & $\mathrm{Ti}_{3} \mathrm{SiC}_{2}$ & 20 & $\mathrm{Ti}_{3} \mathrm{SiC}_{2}$ & $\mathrm{Ti}_{3} \mathrm{SiC}_{2}$ & $\mathrm{Ti}_{3} \mathrm{SiC}_{2}$ & $\mathrm{Ti}_{3} \mathrm{SiC}_{2}$ \\
\hline 3 & $\mathrm{Ti}_{3} \mathrm{SiC}_{2}$ & $\mathrm{Ti}_{5} \mathrm{Si}_{3} \mathrm{Cx}$ & $\mathrm{Ti}_{3} \mathrm{SiC}_{2}$ & $\mathrm{Ti}_{3} \mathrm{SiC}_{2}, \mathrm{TiC}$ & 21 & $\mathrm{Ti}_{3} \mathrm{SiC}_{2}$ & $\mathrm{Ti}_{5} \mathrm{Si}_{3} \mathrm{Cx}$ & unknown & $\mathrm{Ti}_{5} \mathrm{Si}_{3} \mathrm{Cx}$ \\
\hline 4 & $\mathrm{Ti}_{3} \mathrm{SiC}_{2}$ & $\mathrm{Ti}_{5} \mathrm{Si}_{3} \mathrm{Cx}$ & $\mathrm{Ti}_{3} \mathrm{SiC}_{2}$ & $\mathrm{Ti}_{5} \mathrm{Si}_{3} \mathrm{Cx}$ & 22 & $\mathrm{Ti}_{3} \mathrm{SiC}_{2}$ & $\mathrm{Ti}_{3} \mathrm{SiC}_{2}$ & unknown & $\mathrm{Ti}_{5} \mathrm{Si}_{3} \mathrm{Cx}$ \\
\hline 5 & $\mathrm{Ti}_{3} \mathrm{SiC}_{2}$ & $\mathrm{Ti}_{3} \mathrm{SiC}_{2}$ & $\mathrm{Ti}_{5} \mathrm{Si}_{3} \mathrm{Cx}$ & $\mathrm{Ti}_{5} \mathrm{Si}_{3} \mathrm{Cx}$ & 23 & $\mathrm{Ti}_{3} \mathrm{SiC}_{2}$ & $\mathrm{Ti}_{5} \mathrm{Si}_{3} \mathrm{Cx}$ & $\mathrm{Ti}_{5} \mathrm{Si}_{3} \mathrm{Cx}$ & $\mathrm{Ti}_{5} \mathrm{Si}_{3} \mathrm{Cx}$ \\
\hline 6 & $\mathrm{Ti}_{3} \mathrm{SiC}_{2}$ & $\mathrm{Ti}_{3} \mathrm{SiC}_{2}$ & $\mathrm{Ti}_{5} \mathrm{Si}_{3} \mathrm{Cx}$ & $\mathrm{Ti}_{3} \mathrm{SiC}_{2}$ & 24 & $\mathrm{Ti}_{3} \mathrm{SiC}_{2}$ & $\mathrm{Ti}_{3} \mathrm{SiC}_{2}$ & $\mathrm{Ti}_{3} \mathrm{SiC}_{2}$ & $\mathrm{Ti}_{5} \mathrm{Si}_{3} \mathrm{Cx}$ \\
\hline 7 & $\mathrm{Ti}_{3} \mathrm{SiC}_{2}$ & $\mathrm{Ti}_{3} \mathrm{SiC}_{2}$ & $\mathrm{Ti}_{5} \mathrm{Si}_{3} \mathrm{Cx}$ & $\mathrm{Ti}_{3} \mathrm{SiC}_{2}$ & 25 & $\mathrm{Ti}_{3} \mathrm{SiC}_{2}$ & $\mathrm{Ti}_{3} \mathrm{SiC}_{2}$ & $\mathrm{Ti}_{3} \mathrm{SiC}_{2}$ & $\mathrm{Ti}_{3} \mathrm{SiC}_{2}$ \\
\hline 8 & $\mathrm{Ti}_{3} \mathrm{SiC}_{2}$ & $\mathrm{Ti}_{3} \mathrm{SiC}_{2}$ & $\mathrm{TiC}$ & $\mathrm{Ti}_{3} \mathrm{SiC}_{2}$ & 26 & $\mathrm{Ti}_{3} \mathrm{SiC}_{2}$ & $\mathrm{Ti}_{3} \mathrm{SiC}_{2}$ & $\mathrm{Ti}_{3} \mathrm{SiC}_{2}$ & unknown \\
\hline 9 & $\mathrm{Ti}_{3} \mathrm{SiC}_{2}$ & $\mathrm{Ti}_{3} \mathrm{SiC}_{2}$ & $\mathrm{Ti}_{3} \mathrm{SiC}_{2}$ & $\mathrm{Ti}_{5} \mathrm{Si}_{3} \mathrm{Cx}$ & 27 & $\mathrm{Ti}_{3} \mathrm{SiC}_{2}$ & $\mathrm{Ti}_{3} \mathrm{SiC}_{2}$ & $\mathrm{Ti}_{3} \mathrm{SiC}_{2}$ & $\mathrm{Ti}_{5} \mathrm{Si}_{3} \mathrm{Cx}$ \\
\hline 10 & $\mathrm{Ti}_{3} \mathrm{SiC}_{2}$ & $\mathrm{Ti}_{3} \mathrm{SiC}_{2}$ & $\mathrm{Ti}_{3} \mathrm{SiC}_{2}$ & $\mathrm{TiSi}_{2}$ & 28 & TiSi2 & $\mathrm{Ti}_{3} \mathrm{SiC}_{2}$ & $\mathrm{Ti}_{3} \mathrm{SiC}_{2}$ & $\mathrm{Ti}_{5} \mathrm{Si}_{3} \mathrm{Cx}$ \\
\hline 11 & $\mathrm{Ti}_{3} \mathrm{SiC}_{2}$ & $\mathrm{Ti}_{3} \mathrm{SiC}_{2}$ & $\mathrm{TiSi}_{2}$ & $\mathrm{Ti}_{5} \mathrm{Si}_{3} \mathrm{Cx}$ & 29 & $\mathrm{Ti}_{3} \mathrm{SiC}_{2}$ & $\mathrm{TiSi}_{2}$ & $\mathrm{Ti}_{3} \mathrm{SiC}_{2}$ & unknown \\
\hline 12 & $\mathrm{TiSi}_{2}$ & $\mathrm{Ti}_{3} \mathrm{SiC}_{2}$ & $\mathrm{Ti}_{3} \mathrm{SiC}_{2}$ & $\mathrm{Ti}_{5} \mathrm{Si}_{3} \mathrm{Cx}$ & 30 & $\mathrm{Ti}_{3} \mathrm{SiC}_{2}$ & & $\mathrm{Ti}_{3} \mathrm{SiC}_{2}$ & $\mathrm{Ti}_{5} \mathrm{Si}_{3} \mathrm{Cx}$ \\
\hline 13 & $\mathrm{Ti}_{3} \mathrm{SiC}_{2}$ & $\mathrm{Ti}_{3} \mathrm{SiC}_{2}$ & $\mathrm{Ti}_{3} \mathrm{SiC}_{2}$ & $\mathrm{Ti}_{5} \mathrm{Si}_{3} \mathrm{Cx}$ & 31 & $\mathrm{Ti}_{3} \mathrm{SiC}_{2}$ & & $\mathrm{Ti}_{3} \mathrm{SiC}_{2}$ & $\mathrm{Ti}_{3} \mathrm{SiC}_{2}$ \\
\hline 14 & $\mathrm{Ti}_{3} \mathrm{SiC}_{2}$ & $\mathrm{Ti}_{3} \mathrm{SiC}_{2}$ & $\mathrm{TiC}$ & $\mathrm{Ti}_{3} \mathrm{SiC}_{2}$ & 32 & $\mathrm{Ti}_{3} \mathrm{SiC}_{2}$ & & $\mathrm{Ti}_{5} \mathrm{Si}_{3} \mathrm{Cx}$ & \\
\hline 15 & $\mathrm{Ti}_{3} \mathrm{SiC}_{2}$ & $\mathrm{TiSi}_{2}$ & $\mathrm{TiSi}_{2}$ & $\mathrm{Ti}_{5} \mathrm{Si}_{3} \mathrm{Cx}$ & 33 & $\mathrm{Ti}_{3} \mathrm{SiC}_{2}$ & & $\mathrm{Ti}_{5} \mathrm{Si}_{3} \mathrm{Cx}$ & \\
\hline 16 & $\mathrm{Ti}_{3} \mathrm{SiC}_{2}$ & $\mathrm{TiSi}_{2}$ & $\mathrm{Ti}_{3} \mathrm{SiC}_{2}$ & $\mathrm{Ti}_{3} \mathrm{SiC}_{2}$ & 34 & $\mathrm{Ti}_{3} \mathrm{SiC}_{2}$ & & & \\
\hline 17 & $\mathrm{Ti}_{3} \mathrm{SiC}_{2}$ & $\mathrm{Ti}_{3} \mathrm{SiC}_{2}$ & $\mathrm{Ti}_{3} \mathrm{SiC}_{2}$ & $\mathrm{Ti}_{3} \mathrm{SiC}_{2}$ & 35 & $\mathrm{Ti}_{3} \mathrm{SiC}_{2}$ & & & \\
\hline 18 & $\mathrm{Ti}_{3} \mathrm{SiC}_{2}$ & $\mathrm{Ti}_{3} \mathrm{SiC}_{2}$ & $\mathrm{Ti}_{3} \mathrm{SiC}_{2}$ & $\mathrm{TiC}$ & & & & & \\
\hline
\end{tabular}


Table 4. Calculated fractions of phases formed during diffusion bonding.

\begin{tabular}{|c|c|c|c|c|}
\hline & Sample 1 & Sample 2 & Sample 3 & Sample 4 \\
\hline $\mathrm{Ti}_{3} \mathrm{SiC}_{2}$ & 91.4 & 75.9 & 63.5 & 37.5 \\
\hline $\mathrm{Ti}_{5} \mathrm{Si}_{3} \mathrm{Cx}$ & 2.9 & 13.8 & 18.2 & 43.8 \\
\hline $\mathrm{TiSi} 2$ & 5.7 & 10.3 & 6.1 & 3.1 \\
\hline $\mathrm{TiC}$ & 0.0 & 0.0 & 6.1 & 9.1 \\
\hline unknown & 0.0 & 0.0 & 6.1 & 6.3 \\
\hline Total & 100 & 100 & 100 & 100 \\
\hline
\end{tabular}

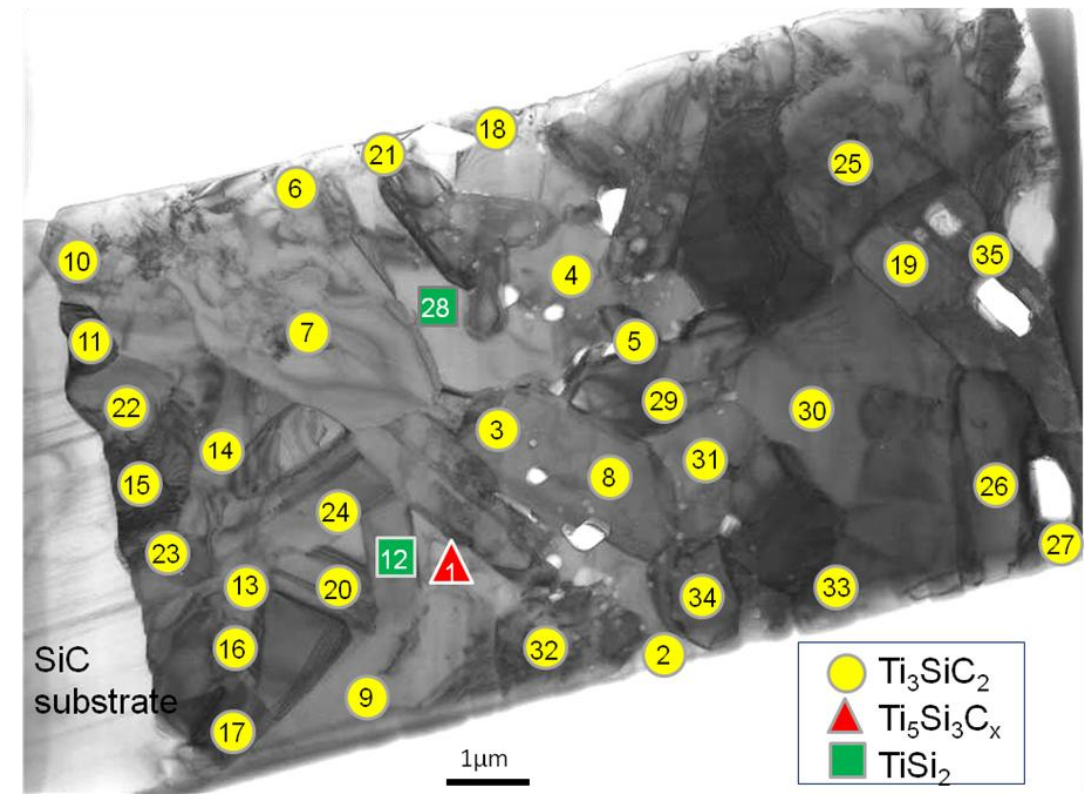

Figure 3. TEM micrograph and determined phases of sample 1.
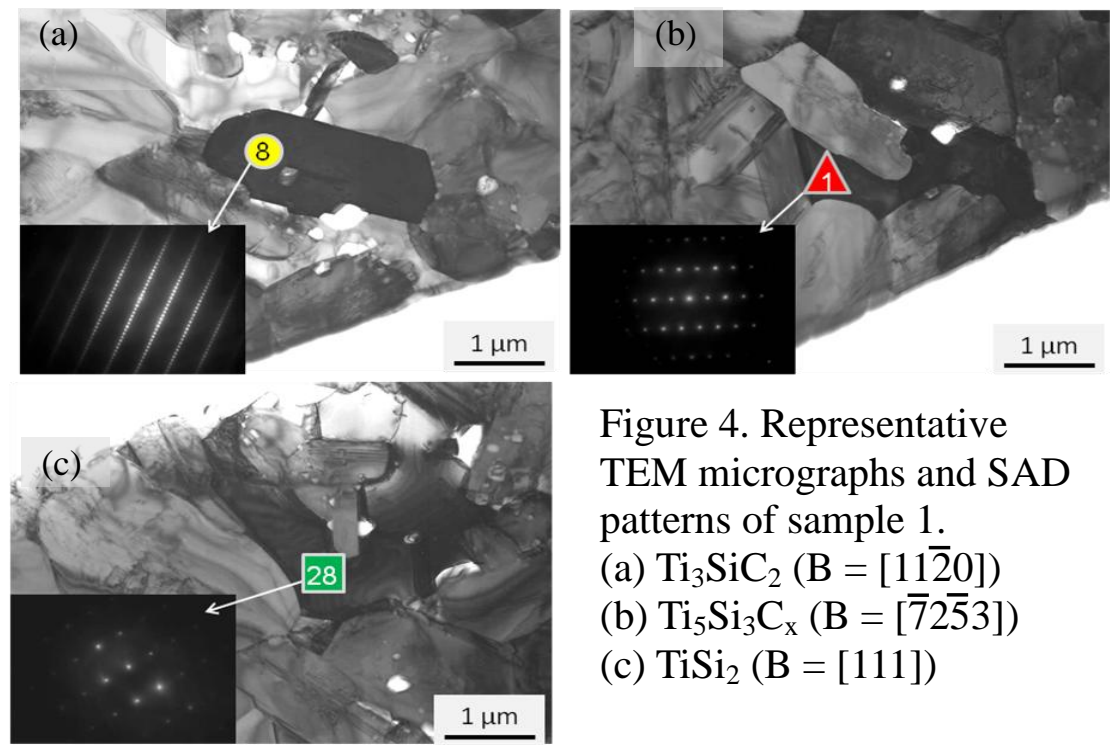

Figure 4. Representative

TEM micrographs and SAD patterns of sample 1 .
(a) $\mathrm{Ti}_{3} \mathrm{SiC}_{2}(\mathrm{~B}=[11 \overline{2} 0])$
(b) $\mathrm{Ti}_{5} \mathrm{Si}_{3} \mathrm{C}_{\mathrm{x}}(\mathrm{B}=[\overline{7} 2 \overline{5} 3])$
(c) $\mathrm{TiSi}_{2}(\mathrm{~B}=[111])$ 
Figure 5 is a TEM micrograph taken from sample 2 in which the determined phases are shown by the different marks. $\mathrm{Ti}_{3} \mathrm{SiC}_{2}, \mathrm{Ti}_{5} \mathrm{Si}_{3} \mathrm{C}_{\mathrm{x}}$, and $\mathrm{TiSi}_{2}$ were again identified. Fractions of the phases are $75.9 \% \mathrm{Ti}_{3} \mathrm{SiC}_{2}, 13.8 \% \mathrm{Ti}_{5} \mathrm{Si}_{3} \mathrm{C}_{\mathrm{x}}$, and $10.3 \% \mathrm{TiSi}_{2}$. It is noted that compared with the case for sample 1, the fraction of $\mathrm{Ti}_{3} \mathrm{SiC}_{2}$ was less and the fraction of $\mathrm{Ti}_{5} \mathrm{Si}_{3} \mathrm{C}_{\mathrm{x}}$ was considerably greater. The reactions between $\mathrm{SiC}$ and $\mathrm{Ti}$ seemed to be complete for a $2 \mathrm{hr}$ hold when the thinner $10 \mu \mathrm{m}$ Ti foil interlayer was used. In contrast, the reaction seemed to be incomplete when processed at the same temperature and for the same hold time when the thicker $20 \mu \mathrm{m}$ Ti interlayer was used.

In Fig. 6, TEM micrograph and determined phases of sample 3 are shown. $\mathrm{Ti}_{3} \mathrm{SiC}_{2}, \mathrm{Ti}_{5} \mathrm{Si}_{3} \mathrm{C}_{\mathrm{x}}, \mathrm{TiSi}_{2}$, and $\mathrm{TiC}$ were detected in sample 3. Moreover, there were also unknown phases. Fractions of the phases were $63.5 \% \mathrm{Ti}_{3} \mathrm{SiC}_{2}, 18.2 \% \mathrm{Ti}_{5} \mathrm{Si}_{3} \mathrm{C}_{\mathrm{x}}, 6.1 \% \mathrm{TiSi}_{2}, 6.1 \% \mathrm{TiC}$, and $6.1 \%$ unknown phase.

Figure 7 shows TEM micrographs and observed phases in sample 4 . The calculated fractions of each phase are $37.5 \% \mathrm{Ti}_{3} \mathrm{SiC}_{2}, 43.7 \% \mathrm{Ti}_{5} \mathrm{Si}_{3} \mathrm{C}_{\mathrm{x}}, 3.1 \% \mathrm{TiSi}_{2}, 9.4 \% \mathrm{TiC}$, and $6.3 \%$ unknown phase. Also, in Fig. 8, representative TEM micrographs and SAD patterns obtained from sample 4 are shown.

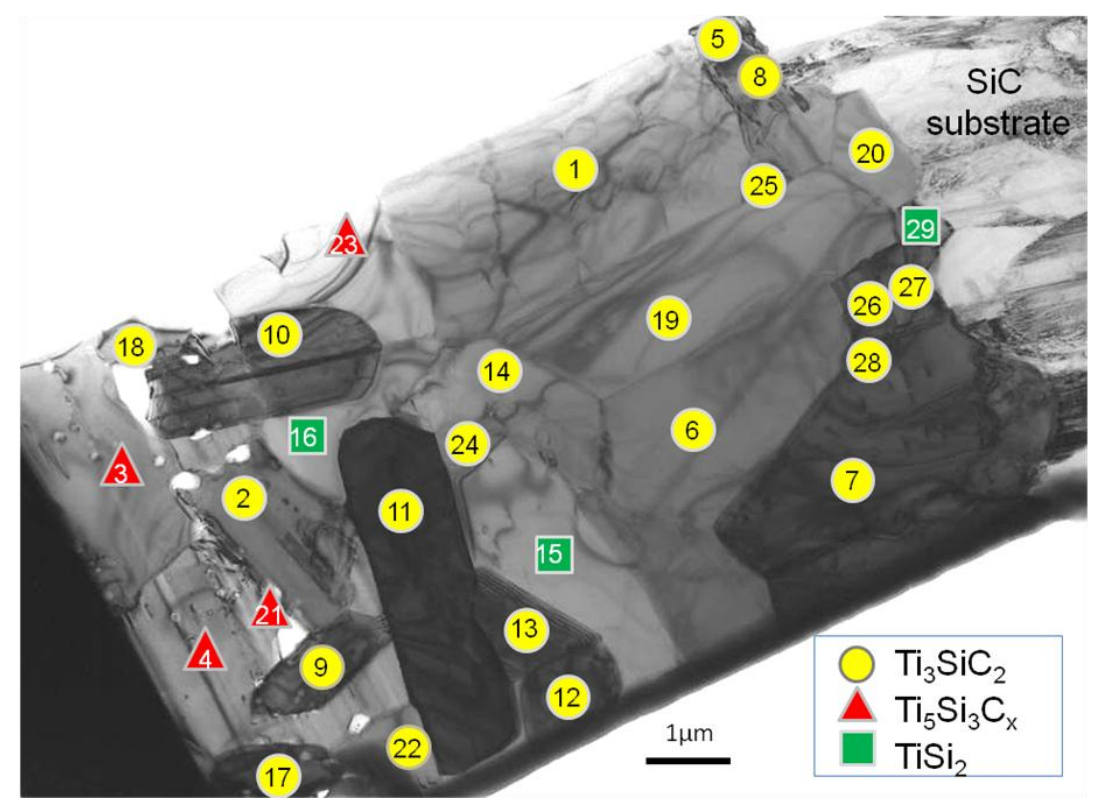

Figure 5. TEM micrograph and determined phases of sample 2.

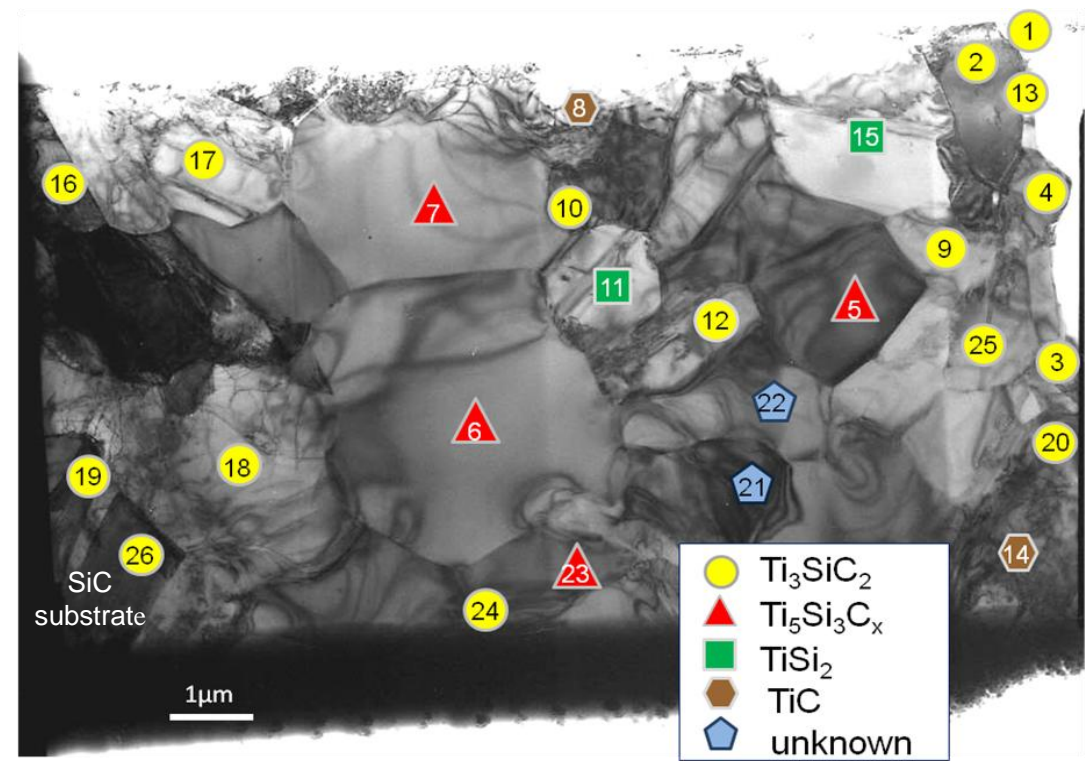

Figure 6. TEM micrograph and determined phases of sample 3. 


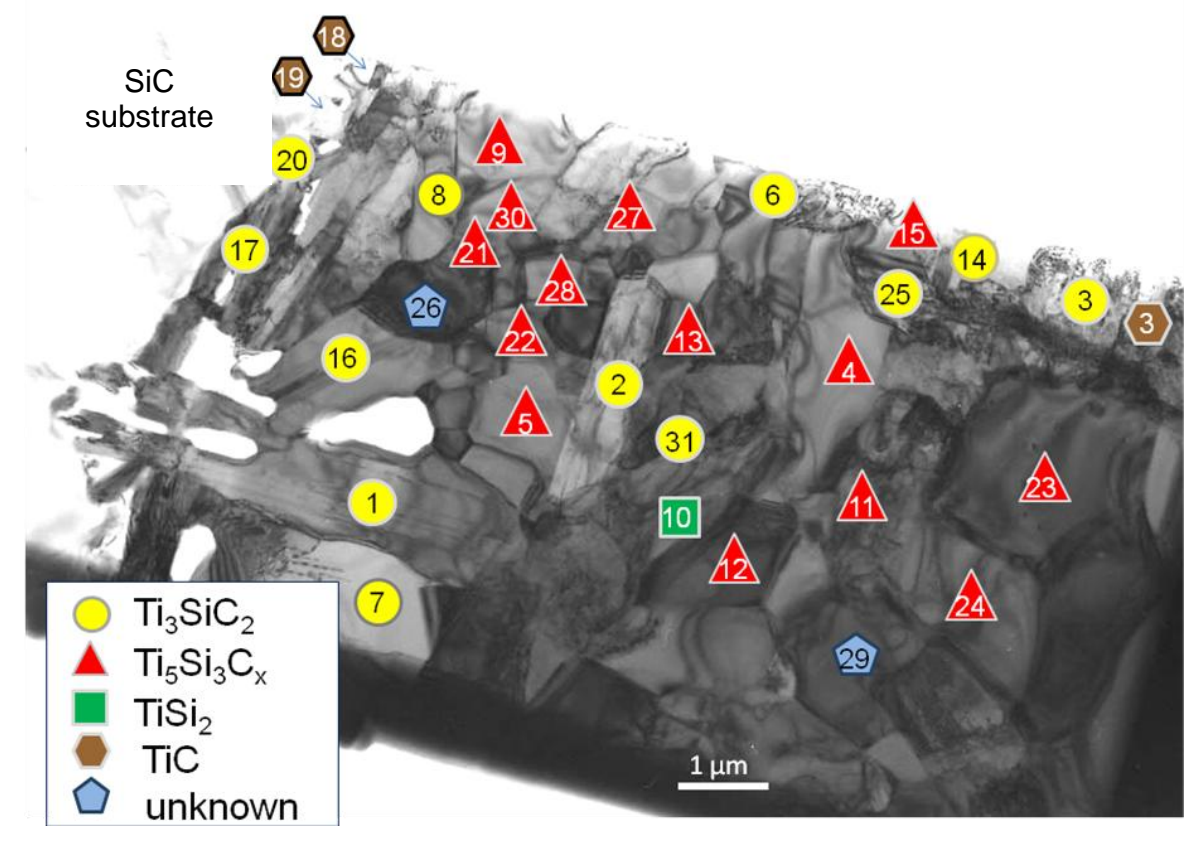

Figure 7. TEM micrograph and determined phases of sample 4.
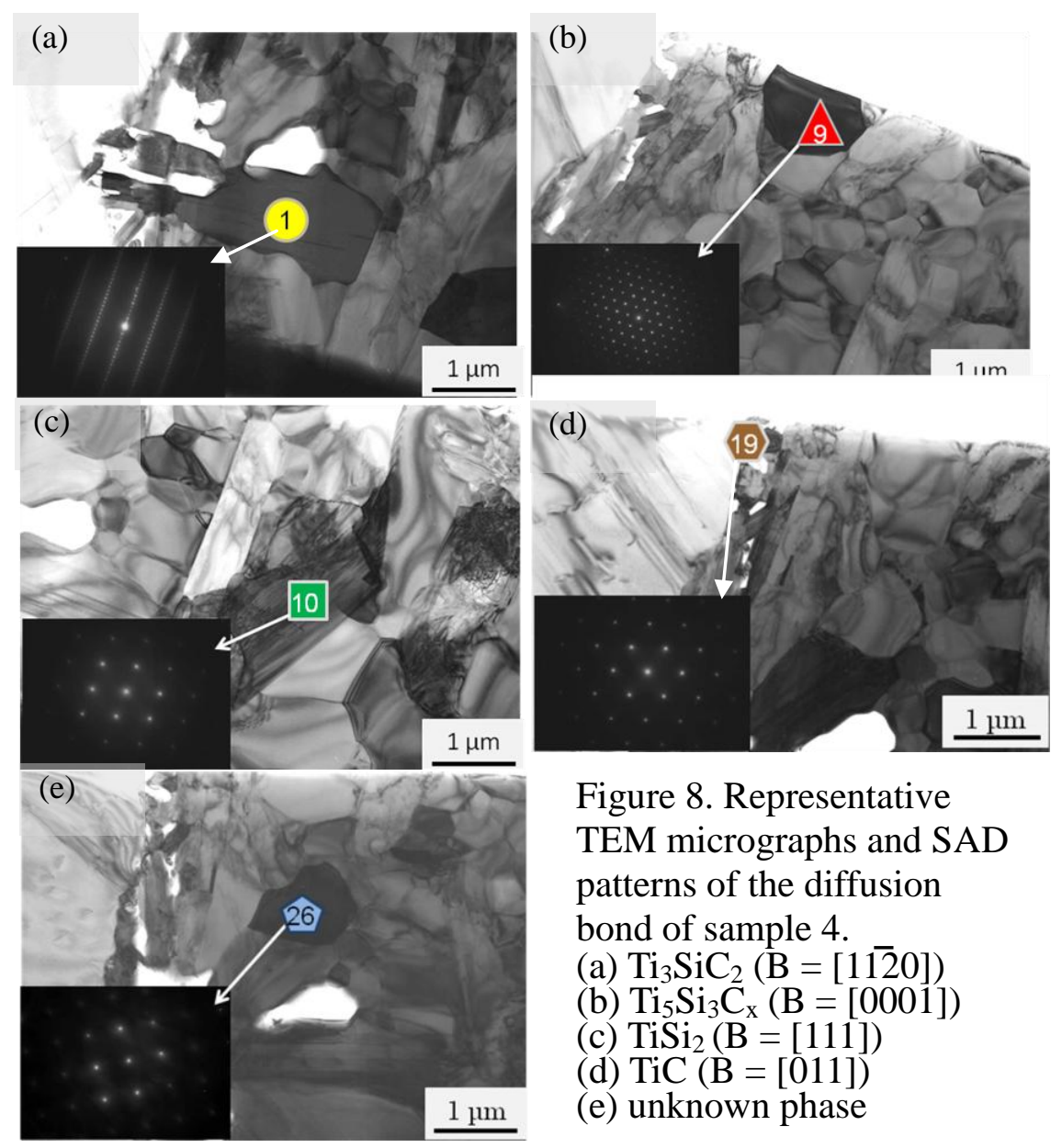

Figure 8. Representative TEM micrographs and SAD patterns of the diffusion bond of sample 4 .
(a) $\mathrm{Ti}_{3} \mathrm{SiC}_{2}(\mathrm{~B}=[1 \overline{12} 0])$
(b) $\mathrm{Ti}_{5} \mathrm{Si}_{3} \mathrm{C}_{\mathrm{x}}(\mathrm{B}=[0001])$
(c) $\mathrm{TiSi}_{2}(\mathrm{~B}=[111])$
(d) $\operatorname{TiC}(\mathrm{B}=[011])$
(e) unknown phase 
Relation between Microstructure and Microcracking

The two sets of joints formed with the PVD Ti interlayer (thicknesses of $10 \mu \mathrm{m}$ and $20 \mu \mathrm{m}$ ) and with the Ti foil interlayer (thicknesses of $10 \mu \mathrm{m}$ and $20 \mu \mathrm{m}$ ) were formed during 2 hour holds at $1250^{\circ} \mathrm{C}$ and $1200^{\circ} \mathrm{C}$, respectively. In the joint for the thinner PVD Ti interlayer, only stable phases were present. Thus, it is assumed that chemical reaction between $\mathrm{SiC}$ substrate and $\mathrm{Ti}$ interlayers had been completed. Thus sample 1 is superior with having no microcracks. While, in the joint with the thicker PVD Ti interlayer (Sample 2), a lot of the detrimental intermediate $\mathrm{Ti}_{5} \mathrm{Si}_{3} \mathrm{C}_{\mathrm{x}}$ grains were detected. According to the literature ${ }^{8}$, it is known that the $\mathrm{Ti}_{5} \mathrm{Si}_{3} \mathrm{C}_{\mathrm{x}}$ has been recognized as a solid solution in which a small atomic percentage of carbon was contained in $\mathrm{Ti}_{5} \mathrm{Si}_{3}$. Also, this intermediate phase has anisotropic thermal expansion ${ }^{13,14}$. As the joint is cooled after processing, mismatches of the coefficient of thermal expansion may induce thermal stresses, and this would explain the reason for microcrack formation observed in sample 2 ,

On the other hand, the joint formed with the $10 \mu \mathrm{m}$ Ti foil (sample 3) and holding for $2 \mathrm{hr}$ at $1200^{\circ} \mathrm{C}$ had almost the same fraction of $\mathrm{Ti}_{5} \mathrm{Si}_{3} \mathrm{C}_{\mathrm{x}}$ observed in sample 2 . However, in sample 3 , a third phase (phase $\mathrm{C}$ ) with composition $37 \mathrm{C} / 43 \mathrm{Si} / 20 \mathrm{Ti}$ was present. The relatively high $\mathrm{Si}$ content in this phase may help increase ductility so that stresses are alleviated and microcracks do not form. Therefore, microcracks were scarcely observed or only very minimal microcracks were observed in sample 3 .

The joints formed with the $20 \mu \mathrm{m}$ Ti foil (sample 4) and holding for $2 \mathrm{hr}$ at $1200^{\circ} \mathrm{C}$ had a different third phase (phase C) with composition 58C/7Si/35Ti (referred to in Table 2 as "common phase A with lower Si content"). In this bond, phase C with low silicon content may be less ductile and therefore contribute to the observed microcracking. The extensive microcracking is mainly attributable to the high fraction of intermediate $\mathrm{Ti}_{5} \mathrm{Si}_{3} \mathrm{C}_{\mathrm{x}}$ phase. If the unknown phase detected in Sample 4 has content similar to that of "common phase A with lower Si content (labeled C)", this may also induce microcracking in sample 4.

\section{CONCLUSION}

Two types of $\mathrm{Ti}$ (PVD coated $\mathrm{Ti}$ on $\mathrm{SiC}$ substrate and metallic Ti foil) with different thicknesses of 10 and $20 \mu \mathrm{m}$ were used to join $\mathrm{SiC}$ to $\mathrm{SiC}$ through diffusion bonding. Joints formed with the PVD Ti coated $\mathrm{SiC}$ were processed at $1250^{\circ} \mathrm{C}$ and joints formed with $\mathrm{Ti}$ foil as an interlayer were processed at $1200^{\circ} \mathrm{C}$. After diffusion bonding, the microstructure of the bonded region was revealed by TEM. The results are summarized as follows.

(1) $\mathrm{Ti}_{3} \mathrm{SiC}_{2}, \mathrm{Ti}_{5} \mathrm{Si}_{3} \mathrm{C}_{\mathrm{x}}$ and $\mathrm{TiSi}_{2}$ were identified in all samples. Furthermore, TiC and unknown phases appeared in the samples in which $\mathrm{Ti}$ foils were used as the interlayer (samples 3 and 4). Furthermore, $\mathrm{Ti}_{3} \mathrm{SiC}_{2}$ formed more and $\mathrm{Ti}_{5} \mathrm{Si}_{3} \mathrm{C}_{\mathrm{x}}$ formed less when samples were processed at a higher temperature and a thinner interlayer was used.

(2) In the sample with $10 \mu \mathrm{m}$ PVD Ti interlayer (sample 1), the fraction of $\mathrm{Ti}_{3} \mathrm{SiC}_{2}$ was highest and the fraction of $\mathrm{Ti}_{5} \mathrm{Si}_{3} \mathrm{C}_{\mathrm{x}}$ was lowest or zero. Thus the sample was superior in terms of having minimal microcracks. On the other hand, in the sample with $20 \mu \mathrm{m}$ PVD Ti interlayer (sample 2), less $\mathrm{Ti}_{3} \mathrm{SiC}_{2}$ and more $\mathrm{Ti}_{5} \mathrm{Si}_{3} \mathrm{C}_{\mathrm{x}}$ formed compared with the case for sample 1. Thus, a lot of microcracking was observed due to the presence of $\mathrm{Ti}_{5} \mathrm{Si}_{3} \mathrm{C}_{\mathrm{x}}$.

(3) Although, in the sample with $10 \mu \mathrm{m}$ Ti foil interlayer (sample 3), microcracks were scarcely observed. This may relate to the presence of a phase with relatively high Si content phase. Moreover, if the unknown phase detected in the sample with $20 \mu \mathrm{m}$ Ti foil interlayer (sample 4) has content similar to that of phase with relatively lower Si content, this may also cause microcracking. ACKNOWLEDGEMENT

H. T. would like to thank Mrs. Taeko Yuki and Mr. Tsukasa Koyama of Osaka Prefecture University for preparing TEM samples using an FIB. 


\section{REFERENCES}

${ }^{1}$ P. J. Lamicq, G. A. Bernhart, M. M. Dauchier, and J. G. Mace, "SiC/SiC Composite Ceramics," Am. Ceram. Soc. Bull., 65 [2] (1986) 336-338.

${ }^{2}$ M. Singh, "A Reaction Forming Method for Joining of Silicon Carbide-based Ceramics," Scripta Materialia, Vol. 37, Issue 8 (1997) 1151-1154.

${ }^{3}$ M. Singh, "Joining of Sintered Silicon Carbide Ceramics for High Temperature Applications," Journal of Materials Science Letters, Vol. 17, Issue 6 (1998) 459-461.

${ }^{4}$ M. Singh, "Microstructure and Mechanical Properties of Reaction Formed Joints in Reaction Bonded Silicon Carbide Ceramics," Journal of Materials Science, 33 (1998) 1-7.

${ }^{5}$ V. Trehan, J.E. Indacochea, and M. Singh, "Silicon Carbide Brazing and Joint Characterization,” J. Mech. Behavior of Materials, Vol. 10, Issue 5-6 (1999) 341-352.

${ }^{6}$ M.G. Nicholas, “Joining Processes: Introduction to Brazing and Diffusion Bonding," Springer (1998).

${ }^{7}$ B. Gottselig, E. Gyarmati, A. Naoumidis, and H. Nickel, "Joining of Ceramics Demonstrated by the Example of SiC/Ti," Journal of the European Ceramic Society, Vol. 6 (1990) 153-160.

${ }^{8}$ M. Naka, J. C. Feng, and J. C. Schuster, "Phase Reaction and Diffusion Path of the SiC/Ti System," Metallurgical and Materials Transactions A, Vol. 28A (1997) 1385-1390.

${ }^{9}$ M. Singh and M.C. Halbig, "Bonding and Integration of Silicon Carbide Based Materials for Multifunctional Applications," Key Engineering Materials, Vol. 352 (2007) 201-206.

${ }^{10}$ M.C. Halbig and M. Singh, "Development and Characterization of the Bonding and Integration Technologies Needed for Fabricating Silicon Carbide-based Injector Components" in "Advanced Processing and Manufacturing Technologies for Structural and Multifunctional Materials II" edited by T. Ohji and M. Singh, CESP, Vol. 29, Issue 9, pp. 1-14, Wiley, NY and American Ceramic Society (2009).

${ }^{11}$ M.C. Halbig and M. Singh, "Diffusion Bonding of Silicon Carbide for the Fabrication of Complex Shaped Ceramic Components," Ceramic Integration and Joining Technologies: From Macro- to Nanoscale, Eds. M. Singh, T. Ohji, R. Asthana and S. Mathur, John Wiley \& Sons, 2011.

${ }^{12}$ J. Ayanne, L. Beaunier, J. Boumendil, G. Ehret and D. Laub, Sample Preparation Handbook for Transmission Electron Microscopy: Techniques, 1st Edition, P. 135, Springer, N.Y., 2010.

${ }^{13}$ J. H. Schneibel and C. J. Rawn, "Thermal Expansion Anisotropy of Ternary Silicides Based on $\mathrm{Ti}_{5} \mathrm{Si}_{3}, "$ Acta Materialia, Vol. 52 (2004) 3843-3848.

${ }^{14}$ L. Zhang and J. Wu, "Thermal Expansion and Elastic Moduli of the Silicide Based Intermetallic Alloys $\mathrm{Ti}_{5} \mathrm{Si}_{3}(\mathrm{X})$ and $\mathrm{Nb}_{5} \mathrm{Si}_{3}$," Scripta Materiallia, Vol. 38, Issue 2 (1998) 307-313. 